\title{
Unstable climate-growth relations for white spruce in southwest Yukon, Canada
}

Raphaël D. Chavardès ${ }^{1,2, *}$

Lori D. Daniels ${ }^{1}$

Patrick O. Waeber ${ }^{2}$

John L. Innes ${ }^{2}$

Craig R. Nitschke ${ }^{2,3}$

${ }^{1}$ Department of Forest Sciences, University of British Columbia, Vancouver, Canada

${ }^{2}$ Department of Forest Resources Management, University of British Columbia, Vancouver, Canada

${ }^{3}$ Department of Forest and Ecosystem Science, University of Melbourne, Australia

*Corresponding author: Department of Forest Sciences, University of British Columbia, 2424 Main Mall, Vancouver, British Columbia, V6T 1Z4, Canada

Tel: 1604822 6310; Fax: 1604822 9133; Email:

raphael3@interchange.ubc.ca

Keywords: dendrochronology, climate change, climatic variation, Pacific Decadal Oscillation, Picea glauca

Abbreviations: PDO Pacific Decadal Oscillation, CATT Champagne Aishihik Traditional Territory, MS mean sensitivity, AC1 first order autocorrelation, $\mathrm{r}$ mean series intercorrelation 


\section{ABSTRACT}

We used dendroclimatology to quantify inter-annual to multi-decadal climatic variation effects on white spruce radial growth in southwest Yukon, Canada. Local climate is dry and cold, such that tree growth was primarily moisture- rather than temperature-limited, although the mechanisms varied temporally. During the $20^{\text {th }}$ century, significant increases in precipitation countered warming temperatures, so that heat-moisture indices have not changed significantly. Directional climatic change, superimposed on variation due to the Pacific Decadal Oscillation (PDO), resulted in unstable climate-growth relations. Prior to 1977 , ring widths were positively correlated with previous growing season precipitation and warm temperatures had a negative impact, exacerbating moisture limitations in dry years especially during the cool, dry negative PDO phase (1946-1976). After 1977, correlations with previous growing season precipitation became negative and correlations with previous fall and winter precipitation and current year July and August temperatures became positive, although not statistically significant. These changes suggest precipitation and temperature increases over recent decades benefitted white spruce growth. Climate projections for this region include further temperature and precipitation increases, which may promote white spruce growth depending on the seasonality and interactions between temperature and precipitation. This study demonstrated the complexity of potential responses of white spruce to climate variation and change.

\section{INTRODUCTION}

Low temperature is a key factor limiting tree growth at high latitudes and elevations, either directly through its influence on heat-dependent ecophysiological processes or indirectly through its influence on growing season length (Tranquillini 1979). The net effect is that temperature regulates rates of photosynthesis and carbon accumulation, which is reflected in radial growth and annual ring widths (Fritts 1976). For example, cool summer temperatures have been shown to limit radial growth of trees growing at high latitude or 
elevation in many areas in northwestern North America, including sites in Alaska (Davi et al. 2003), British Columbia (Wilson and Luckman 2003; Flower and Smith 2011), Alberta (St. George and Luckman 2001) and the Yukon and Northwest Territories (Szeicz and MacDonald 1995; Youngblut and Luckman 2008).

Even at high latitudes and elevations, factors other than low temperature can limit tree growth. For example, Jack pine (Pinus banksiana (Lamb) growth on rock outcrops with thin soils near Yellowknife, Northwest Territories, was found to be positively correlated with growing season precipitation, especially June precipitation (Pisaric et al. 2009). Temperature and precipitation also interact to influence soil moisture availability. Recent studies conducted in northwest Canada and Alaska have shown that many temperature-limited tree-ring chronologies are increasingly sensitive to moisture availability as global and regional temperatures warm (Barber et al. 2000; Davi et al. 2003; D'Arrigo et al. 2004; D'Arrigo et al. 2007; Wilmking et al. 2004; Pisaric et al. 2007). These growth responses vary at a range of spatial scales. Declines in white spruce growth in response to warmer temperatures and drought stress after 1950 are widespread near treelines in Alaska, except in the wettest region, the Alaska Range (Lloyd and Fastie 2002). Differences in climate-growth responses of white spruce were also noted between 
sites in the same study area on the Alaskan Peninsula (Driscoll et al. 2005) and between open forest and treeline sites (Ohse et al. 2012) and among trees within sites in the Brooks and Alaska Ranges (Wilmking et al. 2004).

The average responses of trees to climate can be temporally unstable, with the relative importance of temperature and precipitation varying through time. In north-western North America, the Pacific Decadal Oscillation (PDO) has a strong influence on regional climate (Mantua et al. 1997; Mantua and Hare 2002). During the positive PDO phase, temperature and precipitation are above average along the coast in Alaska and northern British Columbia (Mantua et al. 1997; Hartmann and Wendler 2005), with significant impacts on hydrologic regimes and glacier mass balance (Moore and McKendry 1996; Bitz and Battisti 1999; Hamlet et al. 2005). The PDO also has significant impacts on tree growth along the Pacific coast (Gedalof and Smith 2001; Peterson and Peterson 2001; D'Arrigo et al. 2001; Fagre et al. 2003; Hart et al. 2010) and at continental locations where climate is affected by atmospheric teleconnections (Pisaric et al. 2009, Ohse et al. 2012). Wilmking and Myers-Smith (2008) identified amplified responses in tree ring growth from 1975 onwards that correlated to a PDO shift from the negative to positive phase. This phase change resulted in warmer and drier conditions in the interior of Alaska that 
differed from other PDO shifts during the $20^{\text {th }}$ century, suggesting the recent PDO shift, coupled with climate change, is influencing ecosystems in the region to a much greater extent than in the past (Wilmking and Myers-Smith 2008, Ohse et al. 2012).

In this study, we quantified climate-growth relations during the 20th century for white spruce growing in the Champagne and Aishihik Traditional Territory (CATT), southwest Yukon, Canada. The climate of this area is strongly influenced by the rainshadow of the St. Elias Mountains and increases in precipitation occur during the positive PDO phase (Spooner et al. 2002). Our objectives were (1) determine the importance of precipitation and temperature, and their interaction represented by heat-moisture indices, as limiting factors of white spruce growth at four sites and (2) determine if climate-growth relations were stable or if they differed among two positive phases (1923-1945, 1977-2007) and the intervening negative phase (19461976) of the PDO during the 20th century (Mantua et al. 1997, Gedalof and Smith 2001). The results of this research are important for understanding the potential effects of anticipated future climate on tree growth in this region.

\section{STUDY AREA}

This study was conducted in the CATT in the southwest Yukon Territory, adjacent to Kluane National Park and nearby Haines 
Junction $\left(60^{\circ} 46^{\prime} \mathrm{N} ; 137^{\circ} 35^{\prime} \mathrm{W}\right)$ (Fig. 1). The study area is bounded to the west by the St. Elias Mountains, to the north by the Ruby Range, to the east by the Yukon Southern Lakes and to the south by the Yukon-Stikine Plateau. Dominant soils are Eutric Brunisols on sandy loam morainal or colluvial materials at the bottom of the valleys and Cryosols at higher elevations (Soil Classification Working Group 1998). The CATT has a continental subarctic climate (Kottek et al. 2006), given its location at high latitude in the rainshadow of the St. Elias Mountains (Bonsal et al. 2001; Krebs et al. 2001). The instrumental records for 1961-1990 from the Haines Junction climate station $\left(60^{\circ} 46^{\prime} \mathrm{N}, 137^{\circ} 35^{\prime} \mathrm{W}, 599\right.$ m.a.s.l., Environment Canada 2011) show that mean annual precipitation was $305.7 \mathrm{~mm}, 52 \%$ of which fell as snow from October through April. Mean annual temperature was $2.9^{\circ} \mathrm{C}$, with mean monthly temperatures of 12.6 and $-21.5^{\circ} \mathrm{C}$ for July and January, respectively (Environment Canada 2011). Seasonal to decadal variations in precipitation are influenced by the Aleutian lowpressure cell and the PDO (Edwards et al. 2001; Spooner et al. 2003; Smith et al. 2004).

Forests in the CATT are classified as the Boreal Cordillera Ecozone and belong to the Spruce-Willow-Birch or Boreal White Spruce and Black Spruce zones of the biogeoclimatic ecosystem classification system of British Columbia and Yukon (Meidinger and 
Pojar 1991; Smith et al. 2004). We sampled four sites dominated by white spruce (Picea glauca [Moench] Voss). Sites 1 and 2 were located on warm-aspects in the valley near Lake Aishihik (Aishihik Valley), whereas the Sites 3 and 4 were located near Haines Junction on cool aspects (Fig. 1; Table 1). Forest health records, confirmed by field observations, indicate that a regional spruce bark beetle (Dendroctonus rufipennis [Kirby]) outbreak did not affect trees at Site 1, had minimal impacts on trees at Site 2, but impacted the dominant canopy trees at Sites 3 and 4 between 1995 and 2002. At the latter two sites, dead trees were salvage harvested and were not included in this study. Lastly, the study area is located far from large urban or industrial developments so air pollution was unlikely to have influenced tree growth over the study period (Lloyd and Bunn 2007).

\section{METHODS}

\subsection{SITE-LEVEL CLIMATE RECORDS}

The adjusted and homogenized precipitation and temperature records for Haines Junction start in 1945, making them relatively short, and have many missing values after 1983 (Vincent et al. 2002, Mekis and Vincent 2011). We therefore used ClimateWNA (Wang et al. 2012), a climate mapping system based on regression modelling, to derive climate records from 1923 to 2007 for our four study sites and Haines Junction; the latter was included to directly compare the empirical and 
modelled data. The climate parameters were monthly total precipitation and monthly mean, minimum and maximum temperatures. Comparison of the 1945-1983 empirical and modeled climate data for Haines Junction indicated similar temperature and precipitation ranges and consistent seasonal trends. Monthly temperatures were strongly correlated $\left(r^{2}=0.998,0.997,0.997\right.$ and $n$ $=465,466,466$ for mean, minimum and maximum values, respectively). The correlation for monthly precipitation was statistically significant but weaker $\left(r^{2}=0.452, n=453\right)$, reflecting to greater spatial and temporal variance in precipitation than temperature records (Wang et al. 2012). Comparison of the modelled climate records for 1923-2007 among the four study sites and Haines Junction showed strong inter-site correlations for mean, minimum and maximum temperatures $(\mathrm{r}=0.983$ to 0.999$)$ and precipitation $(\mathrm{r}=$ 0.733 to 0.999$)$. For precipitation, the weaker correlations were between the two northern sites (Sites 1 and 2) and the southern sites (Sites 3 and 4) located near Haines Junction (Figure 1).

Using the site-level monthly climate records (Sites 1 to 4 and Haines Junction), we calculated monthly heat-moisture indices as follows (after Wang et al. 2006):

$$
\text { Heat-moisture index monthly }=\left(\mathrm{T}_{\text {mean }}+10\right) /(\mathrm{P} / 100)
$$


where, $\mathrm{T}_{\text {mean }}$ is the monthly mean temperature $\left({ }^{\circ} \mathrm{C}\right)$ and $\mathrm{P}$ is monthly total precipitation $(\mathrm{mm})$. High indices result from warm temperatures or low precipitation and indicate low moisture availability.

Annual climate variables also were calculated using the sitelevel monthly climate records. Annual total precipitation (sum of monthly values) and mean temperature (average of monthly values) were for the biological year from September through August, which corresponds to the fall, winter and spring months prior to ring formation and the summer months concurrent with ring formation. Annual heat-moisture indices were calculated as follows (after Wang et al. 2006):

$$
\text { Heat-moisture index } \text { annual }=\left(\mathrm{T}_{\text {mean }}+10\right) /(\mathrm{P} / 1000)
$$

where, $\mathrm{T}_{\text {mean }}$ is the mean annual temperature $\left({ }^{\circ} \mathrm{C}\right)$ and $\mathrm{P}$ is annual total precipitation $(\mathrm{mm})$.

We used the modelled climate data for Haines Junction to represent the study area and tested for temporal stability in monthly and annual climate variables. Analysis of variance and Tukey post hoc tests were used to compare monthly and annual mean temperature, precipitation and heat-moisture indices for the three PDO phases 1923-1945, 1946-1976 and 1977-2007. Linear regression was used to quantify annual trends from 1923 to 2007. For 
all tests, $\alpha$ was 0.05 .

\subsection{TREE-RING CHRONOLOGIES}

We developed four new site-specific ring-width chronologies for white spruce, using the increment cores from trees $(\mathrm{dbh} \geq 7.5 \mathrm{~cm})$ sampled in 2008/9 to reconstruct multiple aspects of forest dynamics (Waeber 2012). We sampled increment cores ca. $30 \mathrm{~cm}$ from the ground and ensured they included or were near the pith, providing the longest ring-width series possible per tree. For this study, we analyzed one core from each living white spruce that established prior to 1950 and excluded trees with external scars, blue stain in the sapwood, or releases and suppressions in ring-widths following the spruce beetle outbreak in the 1990s. A subset of 86 trees met these criteria $(n=19$, 19,18 and 30 at Sites 1 to 4, respectively). The cores were prepared following standard dendrochronological procedures and visually crossdated (Stokes and Smiley 1996, Yamaguchi 1991). Ring widths were measured to an accuracy of $0.001 \mathrm{~mm}$ using a stereozoom microscope and Velmex measuring bench interfaced with the program MeasureJ2X. The resulting ring-width series for each site were statistically crossdated using the program COFECHA (GrissinoMayer 2001). This program generates a master series (e.g., the average ring-width for each year) and calculates correlation coefficients between individuals and the master series. Only series 
with correlations $\geq 0.5$ over the lifespan of the tree were combined into the ring-width chronologies to represent average tree growth at each site ( $\mathrm{n}=16,14,14$ and 26 at Sites 1 to 4, respectively).

We used the program ARSTAN to detrend individual series and drive site-specific standard and residual chronologies (Cook and Holmes 1986; Cook 1985). The same standardization procedure was applied to all four sites. First, to account for the non-climatic, agerelated trend in ring widths of our relatively young trees, we fit a negative exponential curve or linear regression through each ringwidth series. We applied a second detrending to account for potential variation due to stand-level disturbance from spruce bark beetle by using a 60 -year spline with a $50 \%$ frequency response. This conservative spline preserves $>95 \%$ of the variation in each ring-width series at a wavelengths $<31$ years, the period of interest in our study. We calculated three descriptive statistics for each of the resulting sitespecific chronologies (Fritts 1976). The mean series intercorrelation $(\mathrm{r})$ is the coefficient derived from a correlation matrix of all series included in the chronology; high values indicate that trees respond similarly to coarse-scale climate and environmental variation. Mean sensitivity (MS) measures ring-width variability between successive years; high values indicate large amounts of inter-annual variation in 
tree growth. First order autocorrelation (AC1) is a measure of temporal autocorrelation within the chronology.

\subsection{CLIMATE-GROWTH RELATIONSHIPS}

Using the site-specific residual chronologies and modelled climate data, we compared climate-growth relationships for two positive phases (1923-1945, 1977-2007) and one negative phase (1946-1976) of the PDO (Mantua et al. 1997, Gedalof and Smith 2001). For analyses using monthly climate data, we used the program Dendroclim2002 (Biondi and Waikul 2004). This program calculates (a) Pearson's product moment correlation coefficients between the ring-widths and monthly climate variables and (b) response function coefficients, which are multivariate estimates from a principal component regression model in which tree-ring values are predicted from monthly climate variables that are standardized and orthagonalized to reduce multicollinearity. For both analyses, $95 \%$ confidence intervals are derived from 1,000 random bootstrapped samples (Biondi and Waikul 2004). Correlation and response functions for monthly total precipitation, minimum, mean and maximum temperatures and heat-moisture indices were calculated for each PDO phase and site, except Site 1. Because most trees at Site 1 established c. 1940, the sample depth for the chronology was insufficient to assess the 1923-1945 phase of the PDO and only the 
1946-76 and 1977-2007 phases were compared for that site. In each analysis, a 15-month window from the June prior to ring formation through August of the year the ring was formed (e.g., summer, fall and winter prior to ring formation plus spring and summer of the year of ring formation) was assessed.

\section{RESULTS}

\subsection{TEMPORAL CLIMATIC VARIATION}

Several significant differences in monthly total precipitation, mean temperature, and heat-moisture indices occurred among the PDO phases (Fig. 2). April was drier and September was wetter during the positive PDO phases relative to the negative PDO. June precipitation increased during successive PDO phases, with a similar but nonsignificant trend in May, July and August. Overall, the positive PDO phases had warmer December, January and March temperatures than the negative phase. April, July and August temperatures were warmer from 1977 to 2007 relative to the previous two phases. The heat-moisture indices were greatest in April when precipitation was lowest; indices gradually decreased throughout the growing season as monthly precipitation increased and temperatures warmed. April heat-moisture indices were greater during the positive than negative PDO phase, concurrent with increased precipitation. Similarly, significant variation in June and September heat-moisture indices 
were concurrent with precipitation. In contrast, January and March heat-moisture indices were consistent with the temperature trends. Annual precipitation, temperature and heat-moisture indices varied significantly among the PDO phases (Table 2). Precipitation increased with subsequent PDO phases resulting in a strong positive slope from 1923 to 2007. Temperature was cooler during the negative PDO phase and warmest during the positive phase from 1977 to 2007, resulting in a long-term positive trend. The heat-moisture indices were lowest during the negative phase of the PDO, concurrent with cooler temperatures. The recent increase in precipitation countered the effects of warmer temperatures, so that heat-moisture indices for 1977-2007 were not different from those in 1923-1945 and the longterm trend was negative indicating less moisture stress, although it was not significant (Table 2).

\subsection{TREE-RING CHRONOLOGY CHARACTERISTICS}

We developed four new site-specific white spruce chronologies (Fig.

3). Series intercorrelations (r) ranged from 0.66 to 0.70 , indicating robust crossdating and trees at each site responded similarly to coarsescale climate and environmental variation. Mean sensitivity (MS) was 0.23 to 0.24 and first order autocorrelation (AC1) was 0.64 to 0.81 , indicating modest variation but high correlation between the ringwidths from one year to the next. These values are similar to other 
white spruce chronologies developed in the Yukon and northern British Columbia (Sziez and MacDonald 1995, Youngblut and Luckman 2008, Flower and Smith 2011).

\subsection{CLIMATE-GROWTH RELATIONS}

The strength and sign of correlations between radial growth and several monthly precipitation, temperature and heat-moisture indices varied among the different phases of the PDO (Figs. 4, 5 and 6). During the positive PDO phase from 1923 to 1945, ring width was positively correlated with precipitation in summer and fall of the year prior to ring formation at Sites 3 and 4 and negatively correlated with winter and spring precipitation at the three sites with sufficiently long chronologies for this analysis. During the negative PDO phase from 1946 to 1976 , the positive relations with prior summer and fall precipitation were stronger and consistent among all four sites (Fig. 4). Relations were strongest for June and October at Sites 1 and 2 and September at Sites 3 and 4. At Sites 3 and 4, the negative growth response to April precipitation of the current year was significant and strong. These relations changed during the positive PDO phase from 1977 to 2007 . Relations changed to weak negative correlations with precipitation in the prior June and July and stronger positive correlations during August through January. Overall, relations were variable and weak for the current spring and summer except the 
strong, significant positive growth response to March precipitation of the current year at Sites 3 and 4.

Maximum temperature had the strongest and most consistent relationships of the monthly temperature variables; results for minimum and mean temperatures are not shown. Like precipitation, maximum temperature-growth relations varied through time (Fig. 5). From 1923 to 1945, relations with maximum temperature were generally negative, except in March. For the year prior to ring formation, the negative growth responses were significant in July at Sites 3 and 4 and November or December at all three sites. The positive relation in March was consistent among sites and strongest at Site 3. From 1946 to 1976 , the negative relations with maximum temperatures in the prior year persisted, especially in June and July. During the current spring and summer, relations were generally negative at Sites 1 and 2 but variable and weak at Sites 3 and 4 . During the positive PDO phase from 1977 to 2007, the strongest and most consistent response to maximum temperature was the significant negative relation in February. The positive response in July and August of the current growing season was consistent among sites and contrasted the previous periods, but was not statistically significant.

The relationships between growth and heat-moisture indices also differed through time, with various effects consistent with results 
for precipitation or maximum temperature (Fig. 6). The predominantly negative relations with the prior summer and winter heat-moisture indices were weak from 1923 to 1945 but became more pronounced from 1946 to 1976, especially in June and October. These negative heat-moisture relations were consistent with the generally positive relations with precipitation and negative relations with maximum temperature during the same months and periods (Figs. 4 and 5). The strong positive relations with heat-moisture indices in April and May from 1923 to 1945 were significant in April at Site 2. The significant positive relation in April persisted in 1946 to 1976 at Sites 3 and 4. These positive relations were consistent with the observed negative relations with the April precipitation and positive relations with May temperature (Figs. 4 and 5). From 1977 to 2007, the significant negative relation with February, particularly at Sites 1 and 2, was consistent with the observed negative relations with maximum temperature (Fig. 5).

\section{DISCUSSION}

\subsection{CLIMATE VARIATION AND CHANGE}

In Yukon Territory, mean annual temperature rose between 1 and $3^{\circ} \mathrm{C}$ in the latter half of the $20^{\text {th }}$ century, with some regions warming more than others (Réale et al. 2003; Field et al. 2007). Consistent with this trend, mean annual temperature at Haines Junction increased 
significantly between 1923 and 2007, although the warming trend was tempered during the negative phase of the PDO from 1946 to 1976 (Table 2). The significant increase during the positive PDO phase from 1977 to 2007 exceeded temperatures during the preceding positive PDO phase from 1923 to 1945, suggesting warm temperature has amplified in recent decades, possibly due to anthropogenic-caused global warming. Similarly, annual precipitation increased through the $20^{\text {th }}$ century, but it was not as strongly affected by the PDO as temperature. The increase in precipitation counteracted potential negative effects of warming, especially after 1977, and resulted in a subtle decreasing trend in the heat-moisture index, suggesting increased moisture availability to trees through time (Table 2).

\subsection{INSTABILITY IN CLIMATIC FACTORS LIMITING GROWTH}

Directional climate change, superimposed on variation due to the PDO, resulted in changes in the climatic factors that limited tree growth during recent decades (Fig. 4, 5 and 6). Climate in the CATT is dry and cold, given its location in the rainshadow of the St. Elias Mountains and northerly latitude. These climatic attributes were pronounced before 1977, particularly under the influence of the negative PDO phase (1946-1976). Before 1977, ring widths were positively correlated with precipitation of the prior growing season 
and correlations were negative with temperature and heat-moisture indices during the previous summer and fall months. The negative relations with temperature could indicate a direct stress in which warm temperatures have exceeded the upper limits of the optimum range for white spruce (D’Arrigo et al. 2004; Lloyd and Bunn 2007). However, given concurrent positive relations with precipitation and prevailing influence of dry and cool regional climate from 1946-1976, the negative temperature relations more likely indicate an indirect effect due to drought stress (Barber et al. 2000; Lloyd and Fastie 2002). Years of low precipitation and/or high temperature resulted in low moisture availability that limited tree growth. Cool temperatures were not limiting, despite the northerly latitude. Rather, warm temperatures had a negative impact on growth, apparently exacerbating moisture limitations in dry years.

The observed interactions between temperature and precipitation are consistent with the complex climate-growth relations documented for white spruce (Ohse et al. 2012). The negative effect of warm temperatures on tree growth in circumpolar boreal forests is widespread, although the causal mechanisms vary among regions and genera (Lloyd and Bunn 2007). Our findings that low precipitation combined with warm temperatures resulted in low moisture availability and limited tree growth are consistent with other research 
on white spruce growing in dry environments. For example, Hogg and Wein (2005) found growth of white spruce is limited by soil moisture in the Takhini area, southwest Yukon. Similarly, Danby and Hik (2007a; 2007b) found evidence growth rates of white spruce in the Yukon are significantly limited by moisture stress as a result of high temperatures. Youngblut and Luckman (2008) identified growing season temperatures in the southwest Yukon, in particular June-July temperatures, exert the primary climatic control on radial growth and growth reductions likely result from temperature-driven drought stress. Wilmking and Juday (2005) found individual trees from white spruce populations in northeast Alaska, adjacent to the Yukon border, exhibited divergent responses to recent changes in climate, with a large number of individuals exhibiting a negative response to warmer temperatures and low precipitation. These trends are consistent at some treeline sites as well where growth declined when average July-August temperatures exceeded the physiological optimum for white spruce in a more northerly study area within the Yukon (D'Arrigo et al. 2004). In addition to this direct, limiting effect of warm temperature, D'Arrigo et al. (2004) suggested temperatureinduced drought stress caused by increases in evapotranspiration and reduced soil moisture limits white spruce growth when temperature increases are not counterbalanced by increases in precipitation which 
maintains available soil moisture. We conclude a similar mechanism was important in the CATT, Yukon prior to 1977.

Climate-growth relations and the factors limiting white spruce growth in the CATT changed after 1977. Temperatures were warmer and most months were wetter relative to the preceding negative PDO phase (1946-1976), consistent with climatic variation documented in northern British Columbia and parts of Alaska (Moore and McKendry 1996; Hartmann and Wendler 2005). Increased precipitation, concurrent with warmer temperatures, alleviated the limiting effect of moisture availability on radial growth. Correlations with precipitation switched from consistently positive to weakly negative for the previous summer. Correlations became consistently positive with current July and August temperatures, although not statistically significant. The positive response of ring widths at all four sites to current summer temperatures supports our assertion that moisture availability was less limiting after 1977 . Our findings imply white spruce growth in the CATT has benefitted from increases in both precipitation and temperatures in recent decades.

Increased precipitation during recent decades in our dry and cold study area is key for understanding the most recent climate-growth responses. Although white spruce growth has become more limited by warm temperatures in recent decades in mesic 
climatic regions (Lloyd and Bunn 2007), other studies conducted in dry, continental climates are consistent with our findings. Both Danby and Hik (2007a; 2007c) and Payette (2007) found growth of white spruce is positively correlated with increases in growing season temperatures when moisture is not limiting. At treeline, increases in white spruce growth in the region have been attributed to increased warming (Danby and Hik 2007a; 2007c). Similarly, Boonstra et al. (2008) identified May and July mean temperatures as the primary predictors of radial growth, and rising temperatures due to climatic warming stimulated tree growth in the Kluane region adjacent to our study area.

\subsection{SPRING CLIMATIC EFFECTS}

During the negative PDO phase, correlations were significantly negative between current April precipitation and ring widths at Sites 3 and 4, the two sites with cool aspects (Fig. 3). The negative correlation indicates more abundant April precipitation corresponded with narrow rings, suggesting a limiting effect more likely due to snow than rain. Although snowfall records for Haines Junction are incomplete, climate normals indicate April is the driest month of the year during which temperatures transition from below to above freezing, marking the change in season and onset of snowmelt (Fig. 2, Environment Canada 2011). During the negative PDO phase, cooler 
winter temperatures in conjunction with more precipitation in April may have resulted in a more persistent snowpack. In this scenario, snowfall in April would limit the length of the growing season and subsequent tree growth, as shown by Vaganov et al. (1999). In contrast, dry Aprils corresponded with wider rings. This climate-growth relation was not as evident on the warm, south-aspect sites (1 and 2) where snowpack would melt more rapidly in spring. Landhäusser et al. (2001) hypothesize that white spruce has a conservative growth strategy under cold soil conditions, which allows it to survive, although growth is limited below soil temperatures of $5^{\circ} \mathrm{C}$ (Wirth et al. 2008). The interaction between soil temperature and moisture also limits the growth and survival of white spruce on sites that have wet and cold soils (Landhäusser et al. 2003; Wirth et al. 2008). Case and Peterson (2007) found lower-than-average snowpacks and longer growing seasons were positively correlated with growth in lodgepole pine (Pinus contorta var. latifolia Engelm. ex S. Watson) in Washington State. Peterson et al. (2002) found subalpine fir (Abies lasiocarpa [Hook.] Nutt.) growth was negatively correlated with winter precipitation and spring snowpack depth, which limits growing season length. They reported low soil temperatures brought upon by delayed snowmelt inhibits the start of the growing season by delaying the onset of budburst and subsequent growth because colder soil and 
air temperatures are maintained later into the summer (Ettl and Peterson 1995). Our findings suggest a similar dynamic may be limiting white spruce growth in our study region.

After 1977, the transition from winter snow accumulation to spring snowmelt apparently shifted from April to March at Sites 3 and 4 and correlations became strongly positive with March precipitation (Fig. 3). In March, mean monthly temperature and the heat-moisture index increased significantly relative to the negative PDO phase, with little increase in precipitation (Fig. 2). We infer these subtle changes mark an earlier snowmelt and transition from snow- to rain-dominated precipitation. This also suggests the growing season is longer during the positive than negative PDO phase, a difference enhanced by recent warming trends.

\subsection{WINTER CLIMATIC EFFECTS}

Tree growth was also affected by winter temperature anomalies after 1977. Radial growth was significantly and negatively correlated to February maximum temperatures at all four sites, with the strongest responses at Sites 1 and 2. This indicates cold (warm) mid-winter temperatures corresponded with wide (narrow) rings. Cold temperatures may facilitate a persistent winter snowpack followed by a slow release of snow and recharge of soil moisture in spring. In contrast, warm maximum temperatures in February, enhanced by 
warmer conditions after 1977, may indicate damage-causing events.

For example, needle desiccation can occur when trees photosynthesize during warm periods in winter while the soil remains frozen and water uptake is limited (Kramer and Kozlowski 1960). The resulting damage to foliage may explain reduced radial growth the subsequent summer (Jacoby and Cook 1981).

\subsection{FUTURE CLIMATE CHANGE AND WHITE SPRUCE}

Climate change projections for southwestern Yukon suggest further temperature increases of 2.9 to $7.1^{\circ} \mathrm{C}$ by the $2080 \mathrm{~s}$, with stronger warming trends in winter than summer (Environment Canada 2011). Annual precipitation is expected to increase, with the greatest increase in winter (Environment Canada 2011). The direction of these changes is consistent with climatic variation observed in our study area between the most recent negative (1946-1976) and positive (1977-2007) PDO phases. Our analyses of climate-growth relations during contrasting PDO phases provide important insights into the potential effects of projected climate change on white spruce.

Specifically, if growing season temperature increases are concurrent with precipitation increases, as projected, then tree growth rates may increase; however, negative impacts on growth could supersede if (i) increases in temperature greatly exceed increases in precipitation, (ii) snowpack increases and persists into the growing season, or (iii) 
damaging winter extremes increase in frequency. Similarly, D'Arrigo et al. (2004) concluded increases in growing season temperatures without a corresponding increase in precipitation will result in reduced white spruce growth in the region.

\section{CONCLUSIONS}

For most of the $20^{\text {th }}$ century, white spruce growth in southwest Yukon was limited by below-average precipitation, interacting with warm summer temperatures and short growing seasons. These limitations to growth were pronounced during the cool, dry negative PDO phase from 1946-1976, but were alleviated with the shift to the warm, wet positive PDO phase after 1977. These changes in climate-growth relations indicate increased precipitation, accompanied by warmer temperatures, has facilitated tree growth over the last 30 years. This region is expected to experience further increases in temperatures and precipitation due to global climate change, with impacts on white spruce growth depending on seasonality and magnitude of the changes. The exact effects of climate change on the future growth of white spruce will be governed by many interacting factors, with local variations within regional trends. This study has demonstrated the complexity of these interactions. 


\section{ACKNOWLEDGEMENTS}

Funding for this project was from the Natural Sciences and Engineering Research Council Strategic Grants program. Permission to work in the area was granted by the Champagne and Aishihik First Nations.

\section{REFERENCES}

Barber VA, Juday GP, Finney BP (2000) Reduced growth of Alaskan white spruce in the twentieth century from temperature-induced drought stress. Nature 405:668-673

Biondi F, Waikul K (2004) DENDROCLIM2002: a C++ program for statistical calibration of climate signals in tree-ring chronologies. Computer Geoscience 30:303-311

Bitz CM, Battisti DS (1999) Interannual to decadal variability in climate and the glacier mass balance in Washington, Western Canada and Alaska. Journal of Climate 12:3181-3196

Bonsal BR, Shabbar A, Higuchi K (2001) Impacts of low frequency variability modes on Canadian winter temperature. International Journal of Climatology 21:95-108

Boonstra R, Desantis L, Krebs CJ, Hik DS. 2008. Cliamte and growth influences on the growth of white spruce trees in the boreal forests of the Yukon. Climate Research 36:123-130

Case MJ, Peterson DL (2007) Growth-climate relations of lodgepole pine in the North Cascades National Park, Washington. 
Northwest Science 81:62-75

Cook ER (1985) A Time Series Analysis Approach to Tree-Ring Standardization. Ph.D Dissertation, University of Arizona, Tucson, Arizona, United States of America

Cook ER, Holmes RL (1986) User manual for program ARSTAN. Tree-ring chronologies of Western North America, California, eastern Oregon and northern Great Basin. Holmes RL, Adams RK, Fritts HC. University of Arizona Press, Tucson, Arizona, United States of America pp 50-65

Danby HK, Hik DS (2007a) Responses of white spruce (Picea glauca) to experimental warming at a subarctic alpine treeline. Global Change Biology 13:437-451

Danby HK, Hik DS (2007b) Variability, contingency and rapid change in recent subarctic alpine tree line dynamics. Journal of Ecology 95:352-363

Danby HK, Hik DS (2007c) Evidence of recent treeline dynamics in southwest Yukon from aerial photographs. Arctic 60:411-420

D’Arrigo R, Villalba R, Wiles G (2001) Tree-ring estimates of Pacific decadal climate variability. Climate Dynamics 18:219-224

D’Arrigo RD, Kaufman RK, Davi N, Jacoby GC, Laskowski C, Myneni RB, Cherubini P (2004) Thresholds for warminginduced growth decline at elevational tree line in the Yukon 
Territory, Canada. Global Biogeochemical Cycles doi:10.1029/2004GB002249

D’Arrigo R, Wilson R, Liepert B, Cherubini P (2007) On the 'Divergence Problem' in Northern Forests: A review of the treering evidence and possible causes. Global and Planetary Change 60:289-305

Davi NK, Jacoby GC, Wiles GC (2003) Boreal temperature variability inferred from maximum latewood density and tree-ring data, Wrangell Mountain region, Alaska. Quaternary Research $60: 252-262$

Driscoll WW, Wiles GC, D’Arrigo RD, Wilmking M (2005)

Divergent tree growth response to recent climatic warming, Lake Clark National Park and Preserve, Alaska. Geophysical Research Letters doi:10.1029/2005GL024258

Edwards M, Mock C, Finney B, Barber V, Bartlein P (2001) Potential analogues for paleoclimate variations in eastern interior Alaska during the past 14,000 yr: Atmospheric-circulation controls on regional temperature and moisture responses. Quaternary Research 20:189-202

Environment Canada (2011) Canadian Climate Normals 1961-1990:

Haines Junction, Yukon. National Climate Data and Information Archive, Ottawa, Ontario, Canada. 
http://climate.weatheroffice.gc.ca/climate_normals/index_1961 _1990_e.html. Accessed July 2011

Ettl GJ, Peterson DL (1995) Growth response of subalpine fir (Abies lasiocarpa) to climate in the Olympic Mountains, Washington, USA. Global Change Biology 1:213-230

Fagre DB, Peterson DL, Hessl AE (2003) Taking the pulse of mountains: ecosystem responses to climatic variability. Climatic Change 59:263-282

Field CB, Mortsch LD, Brklacich M, Forbes DL, Kovacs P, Patz JA, Running SW, Scott MJ (2007) North America. Climate Change 2007: Impacts, Adaptation and Vulnerability. Contribution of Working Group II to the Fourth Assessment Report of the Intergovernmental Panel on Climate Change. Parry ML, Canziani OF, Palutikof JP, van der Linden PJ, Hanson CE. Cambridge University Press, Cambridge, United Kingdom pp $617-652$

Flower A, Smith DJ (2011) A dendroclimatic reconstruction of JuneJuly mean temperature in the northern Canadian Rocky Mountains. Dendrochronologia 29:55-63

Fritts HC (1976) Tree Rings and Climate. Academic Press, London, United Kingdom 
Gedalof Z, Smith DJ (2001) Interdecadal climate variability and regime-scale shifts in Pacific North America. Geophysical Research Letters 28:1515-1518

Grissino-Mayer HD (2001) Evaluating crossdating accuracy: a manual and tutorial for the computer program COFECHA. Tree-Ring Research 57:205-221

Hamlet AF, Mote PW, Clark MP, Lettenmaier DP (2005) Effects of temperature and precipitation variability on snowpack trends in the western United States. Journal of Climate 18:4545-4561

Hart SJ, Smith DJ, Clague JJ (2010) A multi-species dendroclimatic reconstruction of Chilko River streamflow, British Columbia, Canada. Hydrological Processes 24:2752-2761

Hartmann B, Wendler G (2005) The significance of the 1976 Pacific climate shift in the climatology of Alaska. Journal of Climate $18: 4824-4839$

Hogg EH, Wein RW (2005) Impacts of drought on forest growth and regeneration following fire in southwestern Yukon, Canada. Canadian Journal of Forest Research 35:2141-2150

Jacoby GC, Cook ER (1981) Past temperature variations inferred from a 400-year tree-ring chronology from Yukon Territory, Canada. Arctic and Alpine Research 13:409-418

Kramer PJ, Kozlowski TT (1960) Physiology of trees. McGraw-Hill, 
New York, New York, United States of America

Kottek, M, Grieser J, Beck C, Rudolf B, Rubel F. (2006) World map of the Köppen-Geiger climate classification updated.

Meteorologische Zeitschrift 15: 259-263

Krebs CJ, Boutin S, Boonstra R (2001) Ecosystem Dynamics of the Boreal Forest: The Kluane Project. Oxford University Press, New York, New York, United States of America

Landhäusser SM, desRochers A, Lieffers VL (2001) A comparison of growth and physiology in Picea glauca and Populus tremuloides at different soil temperatures. Canadian Journal of Forest Research 31:1922-1929

Landhäusser SM, Silins U, Lieffers VJ, Liu W (2003) Response of Populus tremuloides, Populus balsamifera, Betula papyrifera and Picea glauca seedlings to low soil temperature and waterlogged soil conditions. Scandinavian Journal of Forest Research $18: 391-400$

Lloyd AH, Bunn AG (2007) Responses of the circumpolar boreal forest to $20^{\text {th }}$ century climate variability. Environmental Research Letters 2: 045013 (13pp)

Lloyd AH, Fastie CL (2002) Spatial and temporal variability in the growth and climate response of treeline trees in Alaska.

Climatic Change 52:481-509 
Mantua NJ, Hare SR, Zhang Y, Wallace JM, Francis RC (1997) A Pacific interdecadal climate oscillation with impact on salmon production. Bulletin of the American Meteorological Society $78: 1-11$

Mantua NJ, Hare SR (2002) The Pacific Decadal Oscillation. Journal of Oceanography 58:35-44

Meidinger DV, Pojar J (1991) Ecosystems of British Columbia.

British Columbia Ministry of Forests, Victoria, British Columbia, Canada

Mekis É, Vincent LA (2011) An overview of the second generation adjusted daily precipitation dataset for trend analysis in Canada. Atmosphere-Ocean 49:163-177

Moore RD, McKendry IG (1996) Spring snowpack anomaly patterns and winter climatic variability, British Columbia, Canada. Water Resources Research 32:623-632

Ohse B, Jansen F, Wilmking M (2012) Do limiting factors at Alaskan treelines shift with climatic regimes? Environmental Research Letters 7: $015505(12 p)$

Payette S (2007) Contrasted dynamics of Northern Labrador tree lines caused by climate change and migrational lag. Ecology 88:770780 
Peterson DW, Peterson DL (2001) Mountain hemlock growth responds to climatic variability at annual and decadal scales. Ecology 82:3330-3345

Peterson DW, Peterson DL, Ettl GJ (2002) Growth responses of subalpine fir to climatic variability in the Pacific Northwest. Canadian Journal of Forest Research 32:1503-1517

Pisaric MFJ, Carey SK, Kokelj SV, Youngblut D (2007) Anomalous 20th century tree growth, Mackenzie Delta, Northwest Territories, Canada. Geophysical Research Letters doi:10.1029/2006GL029139

Pisaric MFJ, St-Onge SM, Kokelj SV (2009) Tree-ring Reconstruction of Early-growing Season Precipitation from Yellowknife, Northwest Territories, Canada. Arctic, Antarctic, and Alpine Research 41:486-496

Réale D, McAdam AG, Boutin S, Berteaux D (2003) Genetic and plastic responses of a northern mammal to climate change. Biological Sciences 270:591-596

Smith CAS, Meikle JC, Roots CF (2004) Ecoregions of the Yukon Territory - Biophysical properties of Yukon landscapes. Agriculture and Agri-Food Canada, Summerland, British Columbia, Canada

Soil Classification Working Group (1998) The Canadian System of 
Soil Classification. Natural Resources Canada Research Press, Ottawa, Ontario, Canada

Spooner IS, Mazzuchi D, Osborn G, Gilbert R, Larocque I (2002) A multi-proxy holocene record of environmental change from the sediments of Skinny Lake, Iskut region, northern British Columbia, Canada. Journal of Paleolimnology 28:419-431

St. George RS, Luckman BH (2001) Extracting a paleotemperature record from Picea engelmannii tree-line sites in the central Canadian Rockies. Canadian Journal of Forest Research $31: 457-470$

Stokes MA, Smiley TL (1996) An Introduction to Tree-Ring Dating. University of Arizona Press, Tucson, Arizona, United States of America

Szeicz JM, MacDonald GM (1995) Dendroclimatic reconstruction of summer temperatures in northwestern Canada since A.D. 1638 based on age-dependent modeling. Quaternary Research 44:257-266

Tranquillini W (1979) The Physiological Ecology of the Alpine Timberline. Springer-Verlag, New York, New York, United States of America 
Vaganov EA, Hughes MK, Kirdyanov AV, Schweingruber FH, Silkin PP (1999) Influence of snowfall and melt timing on tree growth in subartic Eurasia. Nature 400:149-151

Vincent LA, Zhang X, Bonasal BR, Hogg WD (2002)

Homogenization of daily temperatures over Canada. Journal of Climate 15:1322-1334

Waeber PO (2012) Integrated Dual Filter Framework for Forest

Management Planning in the Champagne and Ashihik

Treaditional Territory, Southwest Yukon. Unpublished Ph.D.

thesis. University of British Columbia, Vancouver

Wang T, Hamann A, Yanchuck A, O'Neill GA, Aitken SN. (2006)

Use of response functions in selecting lodgepole pine

populations for future climates. Global Change Biology 12:

$2404-2416$

Wang T, Hamann A, Spittlehouse DL, Murdock TQ (2012)

ClimateWNA - High-resolution spatial climate data for western

North America. Journal of Applied Meteorology and

Climatology 51:16-29

Wilmking M, Juday GP, Barber VA, Zald HSJ (2004) Recent climate warming forces contrasting growth responses of white spruce at tree line in Alaska through temperature thresholds. Global Change Biology 10:1724-1736 
Wilmking M, Juday GP (2005) Longitudinal variation of radial growth at Alaska's northern treeline - recent changes and possible scenarios for the 21 st century. Global and Planetary Change 47:282-300

Wilmking M, Myers-Smith I (2008) Changing climate sensitivity of black spruce (Picea mariana Mill.) in a peatland-forest landscape in Interior Alaska. Dendrochronologia 25:167-175

Wilson RJS, Luckman BH (2003) Dendroclimatic reconstruction of maximum summer temperatures from upper treeline sites in Interior British Columbia. The Holocene 13:853-863

Wirth C, Lichstein J W, Dushoff J, Chen A, Chapin F (2008) White spruce meets black spruce: dispersal, postfire establishment, and growth in a warming climate. Ecological Monographs 78:489505

Yamaguchi D (1991) A simple method for cross-dating increment cores from living trees. Canadian Journal of Forest Research 21: $414-416$

Youngblut D, Luckman B (2008) Maximum June-July temperatures in the southwest Yukon over the last 300 years reconstructed from tree rings. Dendrochronologia 25:153-166 


\section{Tables}

Table 1. Biophysical attributes of the four study sites in the CATT, southwest Yukon.

\begin{tabular}{|c|c|c|c|c|c|}
\hline \multirow[t]{2}{*}{ Site } & \multirow[t]{2}{*}{ Location } & \multirow{2}{*}{$\begin{array}{c}\text { Elevation } \\
\text { (m.a.s.l.) }\end{array}$} & \multirow[t]{2}{*}{ Aspect } & \multicolumn{2}{|c|}{ Tree density $\left(\mathrm{ha}^{-1}\right)$} \\
\hline & & & & $\begin{array}{c}\text { Live } \\
\text { (white spruce) }\end{array}$ & Dead \\
\hline \multirow[t]{2}{*}{1} & $61^{\circ} 11^{\prime} 50^{\prime \prime} \mathrm{N}$ & 961 & $\overline{\mathrm{W}}$ & $764(614)$ & 97 \\
\hline & $136^{\circ} 59^{\prime} 22^{\prime \prime} \mathrm{W}$ & & & & \\
\hline \multirow[t]{2}{*}{2} & $61^{\circ} 00^{\prime} 27^{\prime \prime} \mathrm{N}$ & 770 & SW & $1,012(798)$ & 328 \\
\hline & $137^{\circ} 02^{\prime} 32^{\prime \prime} \mathrm{W}$ & & & & \\
\hline \multirow[t]{2}{*}{3} & $60^{\circ} 42^{\prime} 14^{\prime \prime} \mathrm{N}$ & 785 & $\mathrm{NE}$ & $453(428)$ & 194 \\
\hline & $137^{\circ} 20^{\prime} 07^{\prime \prime} \mathrm{W}$ & & & & \\
\hline \multirow[t]{2}{*}{4} & $60^{\circ} 38^{\prime} 06^{\prime \prime} \mathrm{N}$ & 779 & $\mathrm{E}$ & $739(625)$ & 364 \\
\hline & $137^{\circ} 17^{\prime} 31^{\prime \prime} \mathrm{W}$ & & & & \\
\hline
\end{tabular}


Table 2. Comparison of annual (September through August) climate attributes among positive and negative PDO phases from 1923 to 2007. The top three rows show means \pm standard deviations. Within columns, different letters denote significant differences among means. In the bottom row, long-term trends are represented by the slope of a linear regression followed by its $\mathrm{p}$-value. For all statistical tests, $\alpha=$ 0.05 .

\begin{tabular}{ccccc}
\hline Period & $\begin{array}{c}\text { PDO } \\
\text { Phase }\end{array}$ & $\begin{array}{c}\text { Precipitation } \\
(\mathrm{mm})\end{array}$ & $\begin{array}{c}\text { Temperature } \\
\left({ }^{\circ} \mathrm{C}\right)\end{array}$ & $\begin{array}{c}\text { Heat-Moisture } \\
\text { Index }\end{array}$ \\
\hline \hline $1923-1945$ & Positive & $280 \pm 29^{\mathrm{a}}$ & $-1.8 \pm 1.0^{\mathrm{a}}$ & $30.3 \pm 5.1^{\mathrm{a}}$ \\
$1946-1976$ & Negative & $293 \pm 34^{\mathrm{a}}$ & $-2.6 \pm 0.9^{\mathrm{b}}$ & $26.2 \pm 4.6^{\mathrm{b}}$ \\
$1977-2007$ & Positive & $312 \pm 36^{\mathrm{b}}$ & $-1.2 \pm 0.8^{\mathrm{c}}$ & $28.9 \pm 5.0^{\mathrm{a}}$ \\
$1923-2007$ & - & 0.539 & 0.011 & $-0.014(0.528)$ \\
& & $(<0.001)$ & $(0.018)$ & \\
\hline
\end{tabular}




\section{Figure Captions}

Fig. 1 Sites 1, 2, 3 and 4 near Haines Junction in the Champagne and Aishihik Traditional Territory, southwest Yukon.

Fig. 2 Comparison among PDO phases of monthly total precipitation (top), mean temperature (middle) and heat-moisture index (bottom) for Haines Junction, Yukon. For each month, bars represent mean values for the positive PDO phase from1923 to 1945 (left), negative PDO phase from 1946 to 1976 (middle) and positive phase from 1977 to 2007 (right); whiskers are standard deviations; different letters denote significant differences among means $(\alpha=0.05)$. Data are from ClimateWNA (Wang et al. 2012).

Fig. 3 Site-level residual chronologies. For each site, the black line is the standardized ring-width index and the grey line is the sample depth or number of cores included in the chronology in each year. Chronology statistics are sample size (n), mean intercorrelation among series (r), mean sensitivity (MS) and first order autocorrelation (AC1), as defined in the Methods.

Fig. 4 Correlation and response functions between monthly total precipitation and the residual chronologies for Sites 1, 2, 3, and 4 (top to bottom) for the 1923-1945 (left), 1946-1976 (middle) 1977-2007 (right) phases of the PDO. Bars and lines are the correlation function coefficients and their $95 \%$ confidence intervals, respectively; dots are significant response function coefficients $(\alpha=0.05)$.

Fig. 5 Correlation and response functions between monthly maximum temperature and the residual chronologies for Sites 1, 2, 3, and 4 (top to bottom) for the 1923-1945 (left), 1946-1976 (middle) 1977-2007 (right) phases of the PDO. Bars and lines are the correlation function coefficients and their 95\% confidence intervals, respectively; dots are significant response function coefficients $(\alpha=0.05)$.

Fig. 6 Correlation and response functions between monthly heat-moisture indices and the residual chronologies for Sites 1, 2, 3, and 4 (top to bottom) for the 1923-1945 (left), 1946-1976 (middle) 1977-2007 (right) phases of the PDO. Bars and lines are the correlation function coefficients and their $95 \%$ confidence intervals, respectively; dots are significant response function coefficients $(\alpha=$ $0.05)$. 


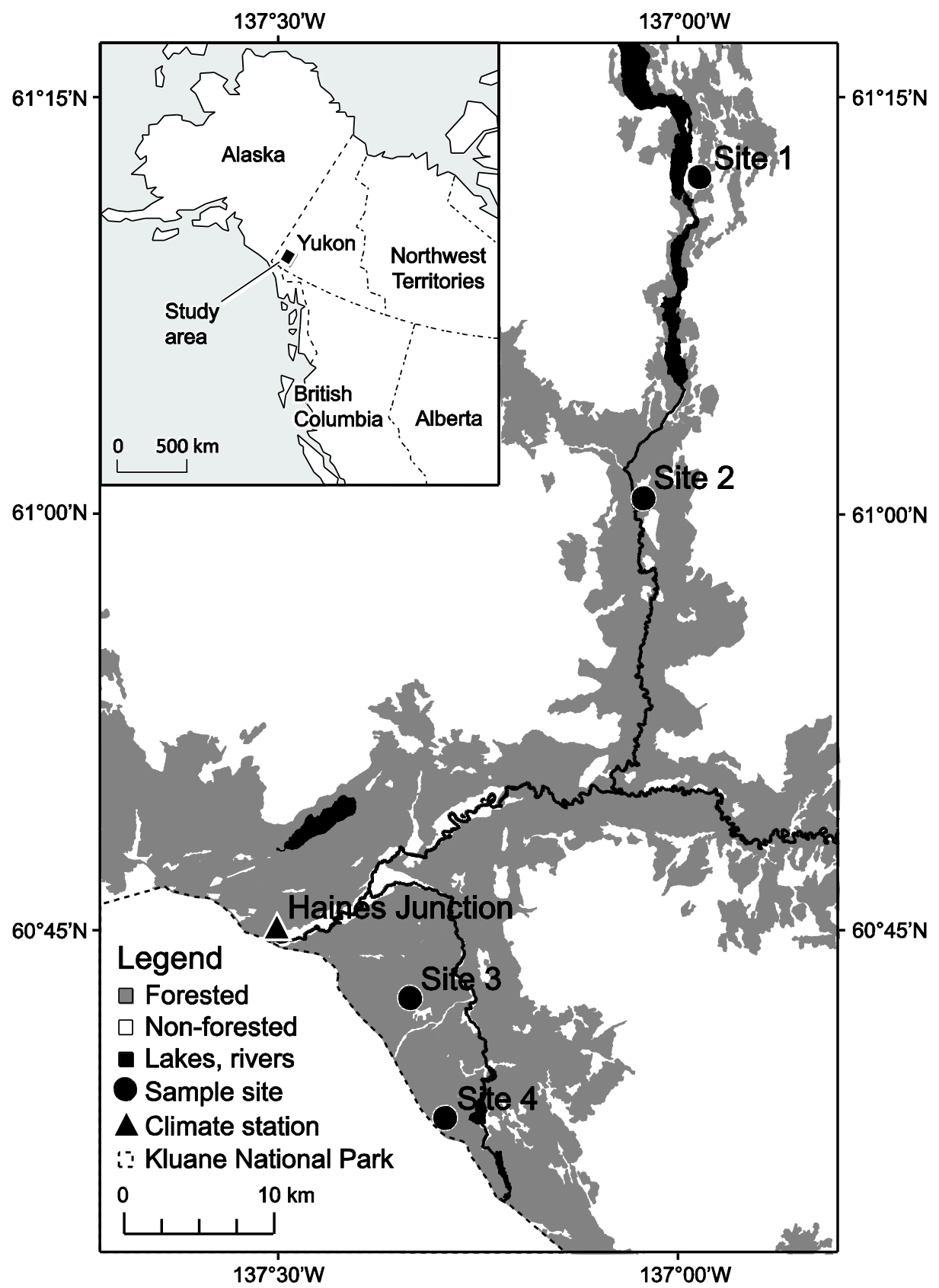




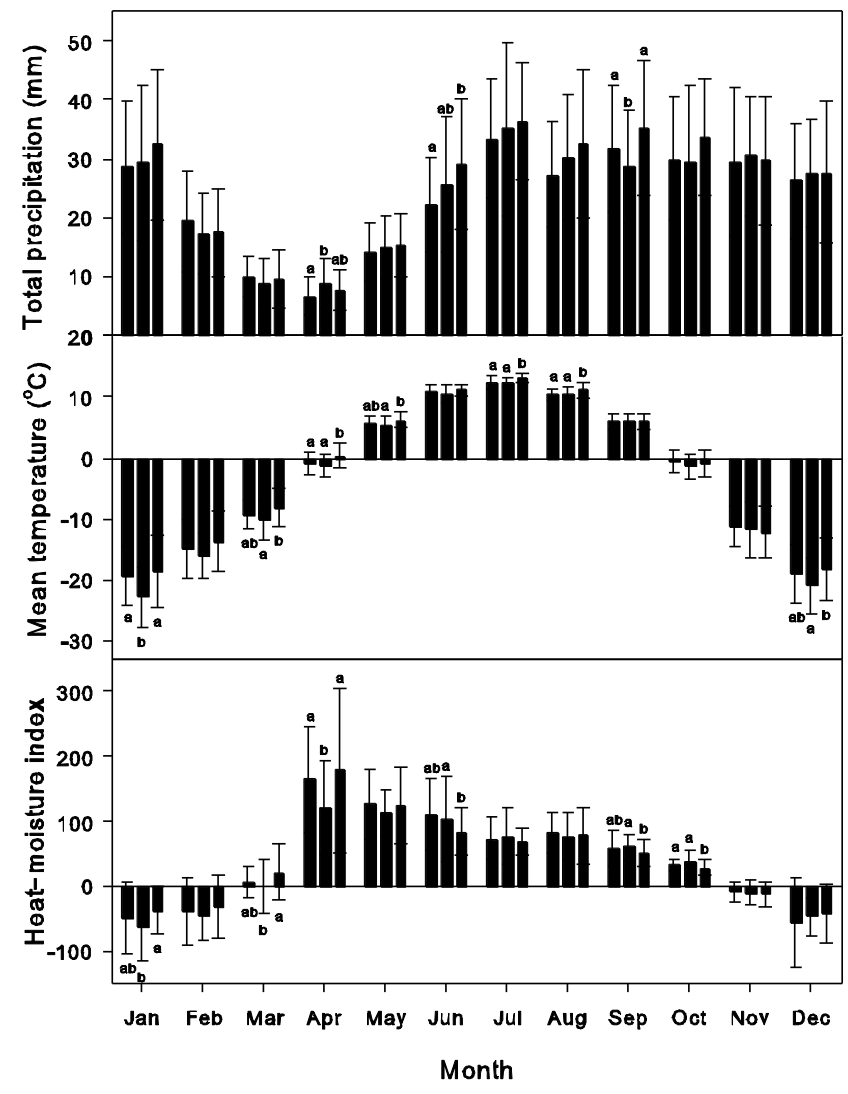




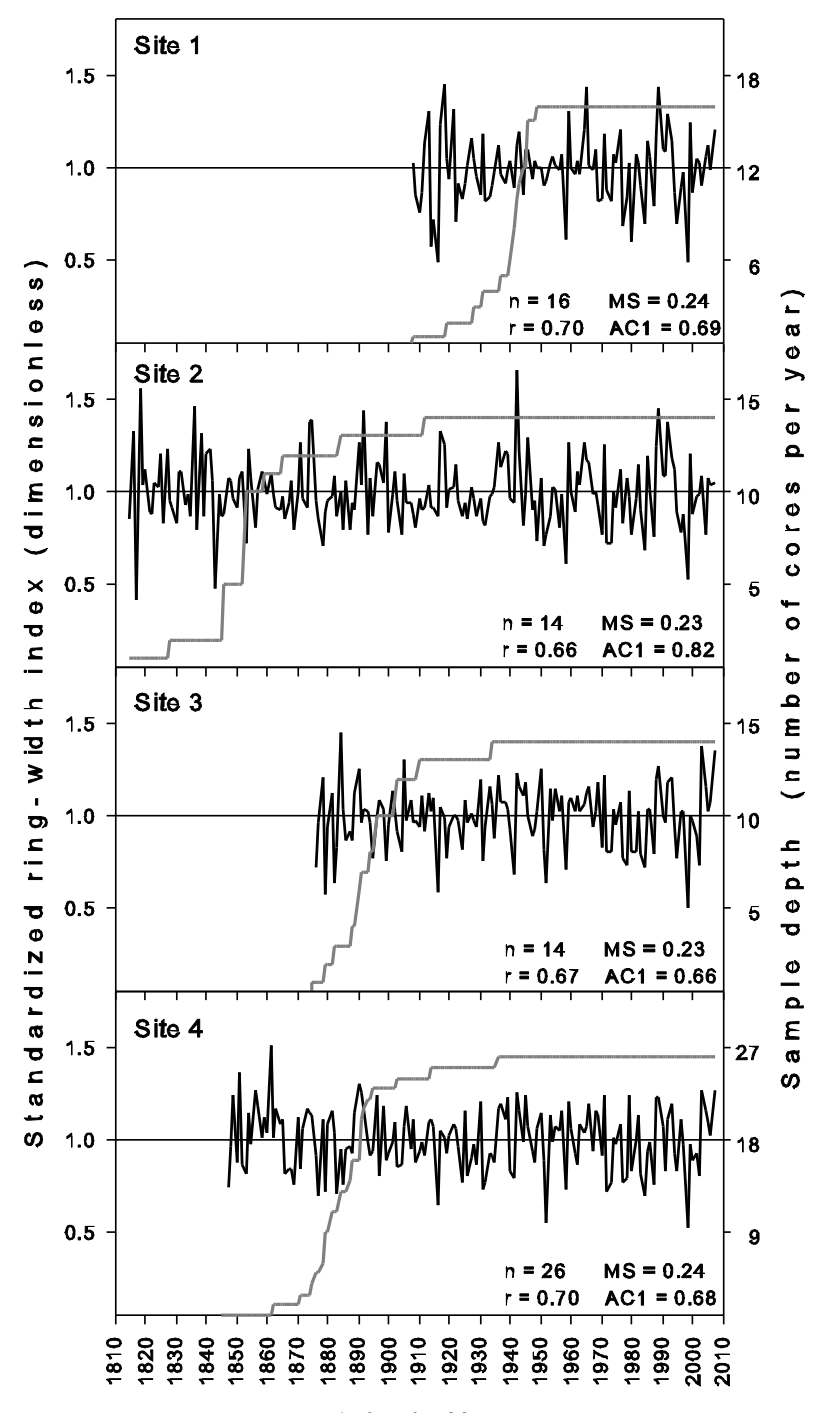




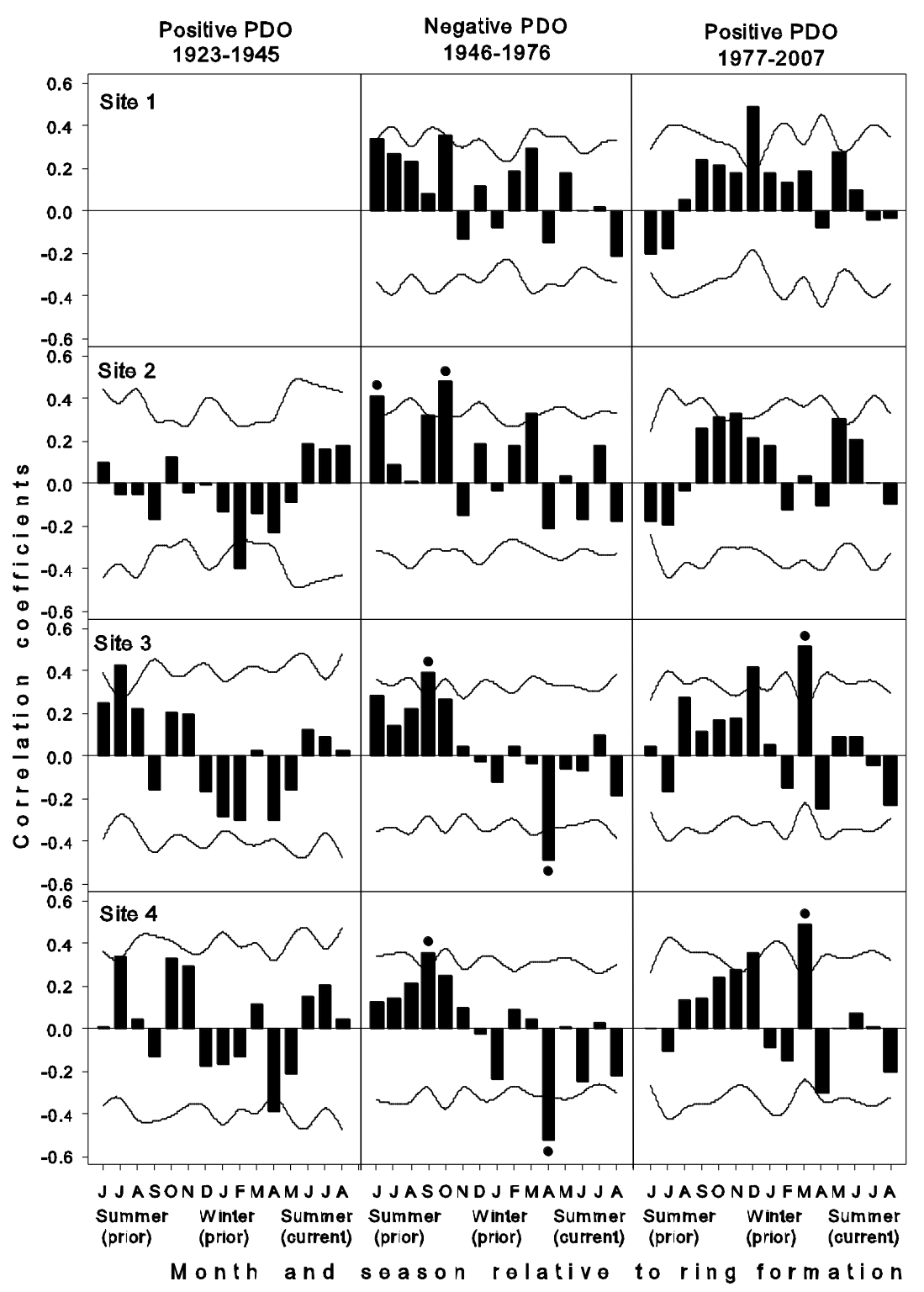




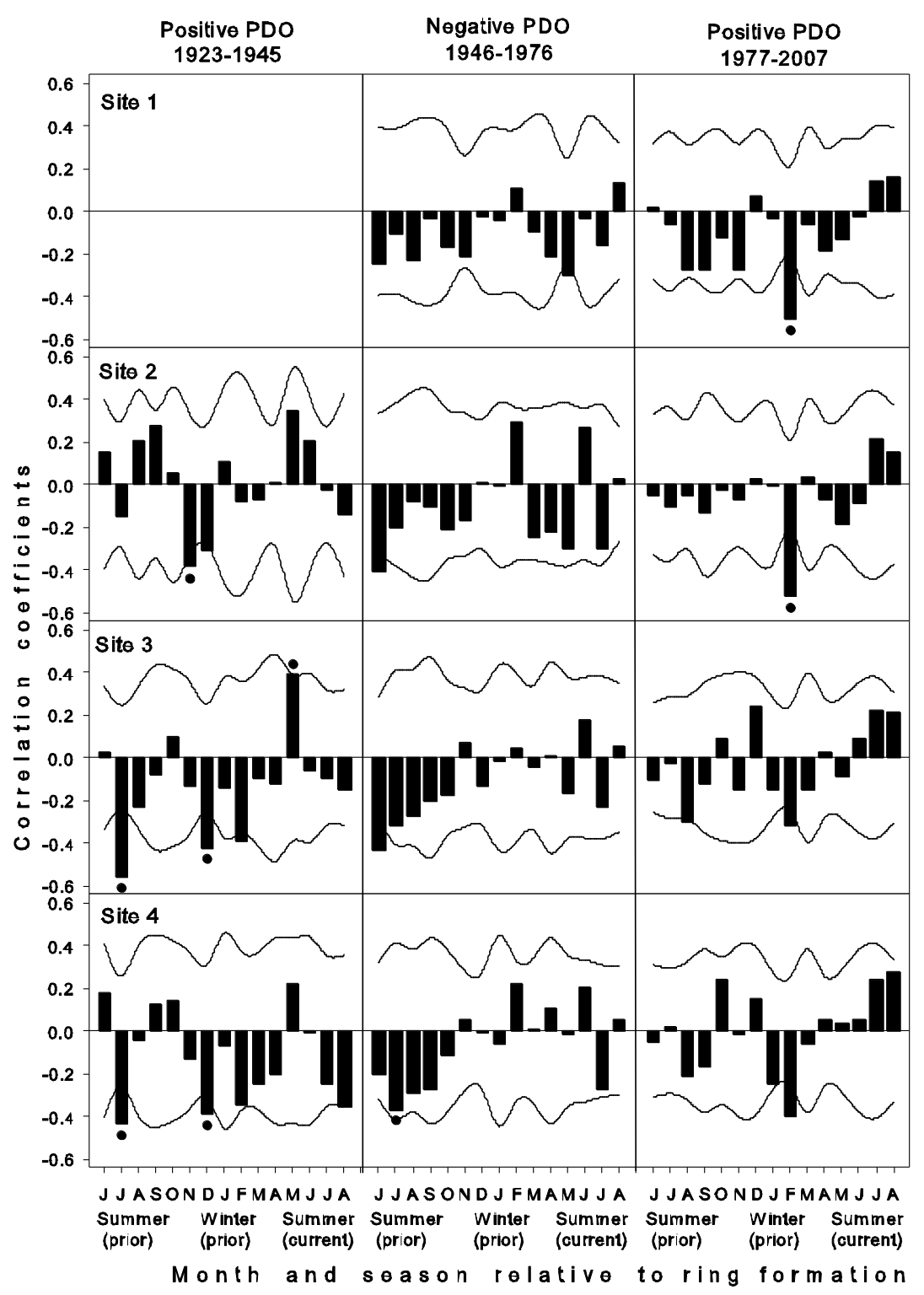




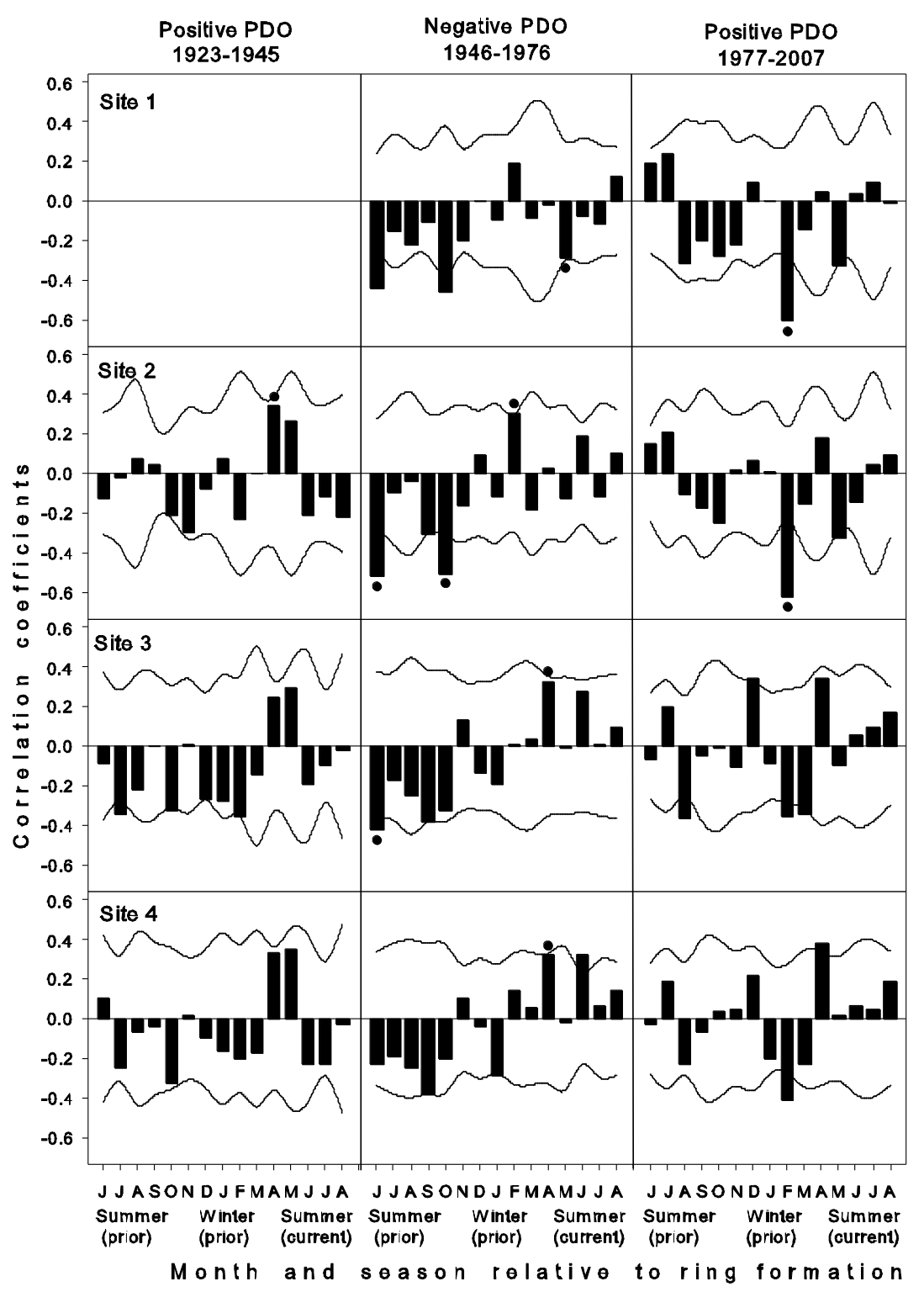




\section{University Library}

\section{- M M I N E R VA A gateway to Melbourne's research publications}

Minerva Access is the Institutional Repository of The University of Melbourne

\section{Author/s:}

Chavardes, RD;Daniels, LD;Waeber, PO;Innes, JL;Nitschke, CR

Title:

Unstable climate-growth relations for white spruce in southwest Yukon, Canada

\section{Date:}

2013-02-01

Citation:

Chavardes, R. D., Daniels, L. D., Waeber, P. O., Innes, J. L. \& Nitschke, C. R. (2013).

Unstable climate-growth relations for white spruce in southwest Yukon, Canada. CLIMATIC CHANGE, 116 (3-4), pp.593-611. https://doi.org/10.1007/s10584-012-0503-8.

Persistent Link:

http://hdl.handle.net/11343/282558 